\title{
Freedom of \\ information. \\ What were \\ they thinking?
}

"The right to know is the right to live."

Aruna Roy (1946- ), Indian social activist

Ongoing dissatisfaction among information requesters, including journalists, has discredited the early and partially heroic narratives of the Aotearoa New Zealand freedom-of-information (FOI) regime. The revolutionary and celebrated Official Information Act 1982 (OIA 1982) has remained virtually unchanged since its inception, despite ongoing calls for reform. This article examines why the OIA 1982 was so transformative, calling on the literature and two thematic analyses of historic parliamentary debates as it explores the thinking of the time and historicises the moment lawmakers cemented in statute notions of an open society. All media rely on this law, and the idea of FOI behind it, to be able to flourish, even if some are more acutely aware of that than others. All media practitioners, from journalists to filmmakers, benefit from the informed social discourse that results from FOI. To explore its failings in Aotearoa New Zealand today and, indeed, to start to imagine remedies, this research argues an important first step is to better understand the thinking of the time.

Keywords: \#transparency \#freedom of information \#the public right to know \#Official Secrets Act 1951 \#Official Information Act 1982 \#Aotearoa New Zealand 
Any history of media practice is also a record of the ideas that sit behind that practice and therefore help shape our mediated social realities in fundamental ways. This article explores the introduction to Aotearoa New Zealand of an idea central to the authentic mediation of political life in any attempt at representative democracy. Freedom of information (FOI) is a 250-year-old idea of universal access that has evolved into a principle with political, legal and ethical dimensions at the centre of modern democracy theory. The idea might be simply described thus: for the will of the people to mean something, citizens must have access to the same information as their rulers

How are leaders to be judged if the body politic is not privy to all the information held by its government? This idea developed into the notion that the wielding of statutory power over others can be kept proportional to requirements, and even legitimised to some degree, through transparency measures placed on the powerful, and against their will if necessary. Today's assumptions for which this idea can be considered a progenitor include those related to our understanding of informed citizenship within an open society. In the end, without the assurances brought by FOI, all media struggles for authenticity. While this study has roots in journalism studies, the research contends all Aotearoa New Zealand's media types - radio, magazines, film, television, web productions, alternative, oppositional, social and indigenous media - rely on the openness that FOI, in large part, is meant to guarantee.

In general terms, the idea of FOI has led liberal democracies to three vital and contemporary assumptions. Firstly, it affirms the individual citizen's presumptive right to information held about them by the State. Secondly, it guarantees the rights of third-party access to information held by the state to increase and maintain government accountability. Thirdly, it affirms the right to involvement by citizens in the making of laws and the affairs of the nation, which cannot be actualised without access to information. The first aspect of FO described here affirms the place and rights of the individual in an open society, the second creates potential for requisite State transparency and the third is a political ideal in monitory and participatory democracies. Indeed, without FOI, a body politic's right to knowledge about the affairs of government - a notion constitutive of the very notion of publics - cannot, in theory, be reliably actualised; informed publics become impossible and mediated political communication struggles for authenticity. David Banisar, whose research into the global spread of FOI laws is widely acknowledged, says FOI is "an essential right for every person. It allows individuals and groups to protect their rights. It is an important guard against abuses, mismanagement and corruption". Professor Patrick Birkinshaw $(2006,41)$ goes further:

FOI is a human right; it enables us to fulfill our potential as humans. Without such rights, we are little more than subjects. Perhaps we are content, but we are still subjects who are denied the right to make integrity and individual responsibility a reality. FOI is both intrinsically and instrumentally important.

This article explores the thinking behind the development of ideals of open government in Aotearoa New Zealand in the late 1970s and the creation of the country's FOI regime in the early 1980s. Given the widely acknowledged parlous and degraded state of FOI in Aotearoa New Zealand in the first two decades of the $21^{\text {st }}$ Century, it seems helpful to start at the introduction of the regime and explore, in historical terms, the thinking behind it.

\section{METHODOLOGY AND DATA}

This study draws from the literature, from document research and from two thematic analyses of parliamentary debates. The historical data analysis on which it draws was conducted as part of a wider, doctoral study and contextualises, in historical and political terms, the passing of the Official Information Act 1982 (OIA 1982). Detailed background to the Act, which is still the engine room of the nation's FOI regime today, is followed by an analysis of verbatim transcripts from New Zealand's parliamentary debates. The relevant transcripts of Hansard, the official record of the New Zealand House of Representatives, were downloaded, coded and analysed to provide a clearer understanding of the political and social motives behind the introduction of the nation's groundbreaking disclosure law. To better understand the failures of today and plan for the remedies of tomorrow, this research contends it is necessary to understand the ambitions of those who designed the regime.

This hermeneutic approach is intended to help illuminate the socio-political context of the country's nascent FOI regime in the early 1980s. The researcher first analysed parliamentary debates surrounding the introduction of the OIA's precursor, the Official Secrets Act 1951 (OSA 1951). Four transcripts of parliamentary debates relating to the OSA 1951 were explored thematically to establish a sense of the territory, in terms of transparency, from which a liberalising Aotearoa New Zealand society was emerging in the 1970s. This helps our 
understanding of both the culture of State secrecy that grew from the OSA 1951 and of the radical shift required to abandon it. The focus here, however, is the introduction of the revolutionary OIA in 1982, which broke that wall of secrecy; the article explores the debates between the divisions of elite political powerbrokers involved in its genesis. The aim is to establish the intentions - and uncertainties - behind its introduction Parliamentary debates from May 1980 until December 1983 which included any discussion of the Act $(n=62)$ were coded thematically. Sixteen primary nodes and a further 30 descendent nodes were created in NVivo analysis software.

The aim was to capture both the spirit and purpose of the law but also its complexity through the categorisation of matters that were still at issue when it was passed. It is intended to articulate a sense of the society that desired to, and then managed to, annul the State's long-held assumption of the right to total secrecy.

\section{THE OFFICIAL INFORMATION ACT 1982}

Before the advent of the OIA 1982, the Government of New Zealand was free to pick and choose what information, if any, it shared with the public. Information held by the State was presumed, in legal terms at least, to be categorically confidential unless specifically approved for disclosure, regardless of its nature. Those who released information without approval were deemed to have committed an offence under the Official Secrets Act 1951, which was a carbon copy of Britain's notorious secrecy act at the time. To be a government employee of virtually any sort meant being "good at keeping secrets". If ignorance is a politically weak position (the corollary of the widely accepted view that knowledge is power), the New Zealand Government had virtually unbridled control over the level of power ceded to the electorate.

At its core, the State was guarded and secretive, having enshrined such legislation to help in its defence against the perceived threats of communism in the middle of the $20^{\text {th }}$ Century. Preoccupied with the threat of being spied on, it prohibited any official from passing information to anyone with catch-all lawmaking.

THE OFFICIAL INFORMATION BILL (OIB)

Growing opposition to the Vietnam War, to Prime Minister Rob Muldoon's 'Think Big' energy policies and, later, to the Springbok rugby tour of 1981 was part of a political awakening that included increasing

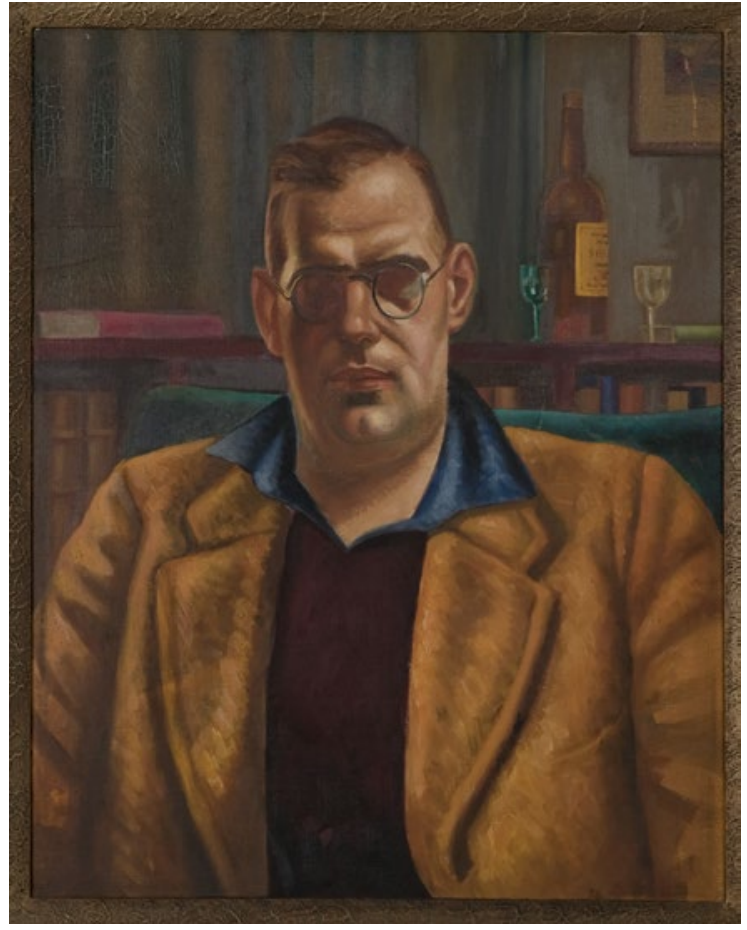

Figure 1. Leo Bensemann, Portrait of Alan Danks, Oil on board, UC-MBL-1985, University of Canterbury Art Collection, Christchurch, New Zealand, www.kohika.canterbury.ac.nz Reproduced with permission.

demands for transparency. Alongside it was increasing consciousness of contemporary Māori land issues, brought to focus by the defining land occupation at Takaparawhā (Bastion Point) in 1977-78 and the principles of tino rangatiratanga (sovereignty). But this awakening came face to face with Muldoon's authoritarian approach, which included such famous confrontations with accountability as the banning of political cartoonist Tom Scott from covering political delegations overseas and even from the Prime Minister's own press conferences. Muldoon declined to halt the Springbok rugby tour that was dividing the country in 1981 and was dismissive of the proposal for an FOI regime, publicly calling the proposed OIA a "nine-day wonder". The Official Information Committee, later dubbed the Danks Committee after its chairman Alan Danks, an economics professor, was formed and directed to review the OSA 1951 and to consider the extent to which official information - a euphemism for any information in government hands - might be made readily available to the public. 
What the Danks committee recommended in its two reports amounted to a fundamental upsetting of the existing relationship between state and people in Aotearoa New Zealand. An "official information act" was proposed to deliberately reverse the presumption of the State's right to secrecy and base a new relationship between the State and citizens, at least in terms of information-sharing, on an underlying principle of availability. That is, all information held by the Government would become available to anyone in New Zealand (unlike many other regimes around the world, rights to official information are not restricted to citizens, or even residents, but are accorded to anyone on New Zealand soil) unless there was good reason for withholding it. Indeed, information could still be kept from the public under the new regime if it met certain strict and narrow criteria but situations demanding such secrecy were now defined in law and restrained principally to matters of state and Crown security, commercial privilege, "free and frank" advice to ministers, and the privacy of natural persons. In global terms, New Zealand's list of reasons for withholding information was comparatively short, one of the factors contributing to the conventional narrative that New Zealand's FOI regime led the world in the creation of state transparency.

The Danks Committee's recommendations were adopted for the most part, despite being radical, and the Official Information Act was passed in 1982 and came into effect the following year. It was roundly celebrated as one of the most liberal and permissive regimes on the planet and in late 1999 the country's chief ombudsman, Sir Brian Elwood, was still happy to declare that New Zealanders' right to know was, as far as he knew, "unmatched". Judith Aitken, a senior civil servant, reminded an open-government conference in England of arguments that transparency was the $20^{\text {th }}$ century's most significant constitutional development and equivalent in scale to the introduction of the male franchise in the $19^{\text {th }}$ century.

\section{DISCUSSION}

The significance of the law was not at issue in parliamentary debates, even though Prime Minister Rob Muldoon was taken to task for belittling it outside the House. The Government parliamentarian most noted for his advocacy of FOI was the member for Hamilton West, Mike Minogue. He told the House a year before the introduction of the Official Information Bill that the parliamentary democracy New Zealand so valued would not survive without FOI reforms. His comment came during the address-in-

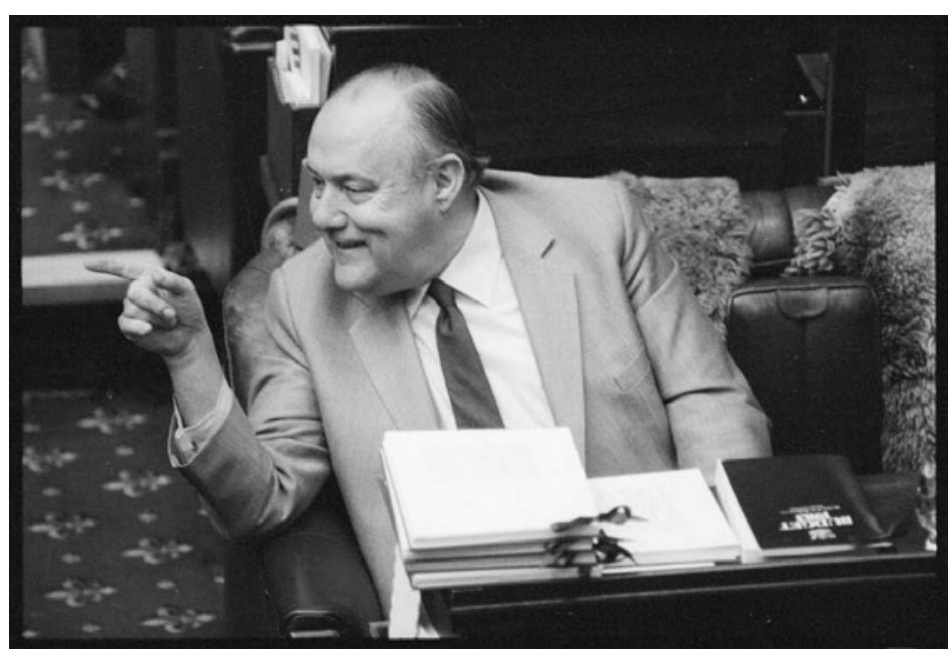

Figure 2. New Zealand Prime Minister, Robert Muldoon, reading the budget (29 July 1983). Dominion Post (newspaper): Photographic negatives and prints of the Evening Post and Dominion newspapers. Ref: EP/1983/2952/6-F. Alexander Turnbull Library, Wellington, New Zealand/records/23222557.

reply in response the Governor-General's speech opening the second session of the $39^{\text {th }}$ Parliament.

I have said on many occasions that I do not think this parliamentary institution can long survive what has become the habitual practice in connection with information. I refer to the growing habit of official secrecy in vital matters. The reason for this growing habit is our continuing support for section 6 of the Official Secrets Act, which has long been used to obscure and conceal information about public affairs. It is quite stupid and untrue to pretend any longer that secrecy has not become the habit of both bureaucracy and politicians. This must change if the health of the institution of Parliament is to be safeguarded.

Analysis of the "importance" node (26 references) showed New Zealand's Parliament was under no illusions about the magnitude of what might be achieved with the passing of the OIA. Except for the Prime Minister's, there was no tangible opposition to the idea that FOI reforms were required or that the goal was the almost-complete political transparency of the State. Introducing the bill, Attorney General Jim McLay apologised for the length of his introductory remarks but 
noted it was "one of the most significant constitutional innovations to be made since the establishment of the office of the Ombudsman in the

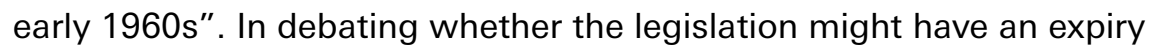
date, a "sunset clause", Minogue said the law proposed to increase citizen rights and, as such, "should be seen as a lasting part of our legal and constitutional fabric".

Underscoring its importance, the Attorney General closed his introductory remarks by returning to the core, constitutional values of FOI:

I reiterate that the Bill represents a significant constitutional innovation. It seeks to improve communication between the citizen and the bureaucracy. It makes governments more accountable to the people. But perhaps, above all, it materially alters the delicate balance that exists between the citizen and the State, not by diminishing the effectiveness of government but rather by greatly increasing the rights of the individual in his or her dealings with an otherwise all-powerful State. In so doing it very substantially enhances the freedoms of each and every New Zealander.

OPPOSITION TO ASPECTS OF THE BILL

The nodes "criticism" and its child nodes "poacher and gamekeeper", "cabinet veto" and "Labour policy" grouped opposition thematically and allowed criticisms of the bill to be explored. Led by Geoffrey Palmer, the MP for Christchurch Central, the Opposition challenge focused on two aspects of the proposed law. The first was the extent to which it still provided for state secrecy in sections 6 and 7 . The second was that the final decision on release of information to requesters lay with the minister whose ministry held the information, and not with the mechanism of appeal, the Ombudsman.

Labour asked what guidelines would help officials decide for or against the release of information because that would affect whether the presumption on balance was for or against disclosure. To ensure the presumption was for disclosure, as the Danks committee intended, the conclusive criteria for withholding information under clause 6 needed to be narrow, since they were the exclusions that did not have to be weighed against the public interest in release, as those in clause 7 did. The most significant reasons for exclusion were listed in clause 6. They were that information can be withheld if releasing it would threaten the security of the nation. That it could undermine the entrustment of New
Zealand with information from other governments. That it threatened the maintenance of law, or could endanger anyone, or seriously damage the New Zealand economy (Official Information Act s. 6). In these cases, officials would not have to run the withholding of information against a public-interest test to establish that it is more in the public interest to withhold it than release it. In the criteria under clause 7, which includes the protection of commercially sensitive material and officials' free and frank advice to their ministers, they would have to run such a test. (Note: after subsequent amendments, the intentions behind clause 7 in the original bill are now found in section 9 of today's act).

While there was broad agreement on the nature of FOI principles, Geoffrey Palmer told the House that the quality of FOI legislation lay in its details. He disagreed "profoundly" with some of the Danks Committee's conclusions, including that government ministers should have the final say on whether information was released or not. There needed to be a "neutral umpire" on FOl disputes. "The Government must surrender the keys to the palace," Palmer told the House. At issue was whether ministers would invoke their right to a veto "frequently" and thereby reduce FOI. He hoped the special select committee to consider the bill would change this aspect of it.

In a terse exchange over the Ombudsman's review role in relation to FOI refusals, Attorney General Jim McLay told the Opposition that the public could expect that a "public-interest" argument for the withholding of information would not "become a synonym for administrative convenience or for the avoidance of political embarrassment". Labour argued having a neutral umpire was a basic tenet of FOI laws. It said a ministerial veto was the sort of concentration of executive power that was at the heart of much current discontent with the Government. However, the Government's response was that making the Ombudsman's FOI rulings binding on parties would be "an abdication of the functions of the Government in favour of some other institution that is neither elected nor responsible in that sense", a situation the Ombudsman's office itself recognised. The Government stressed that it expected the ministerial veto to be used "only in very strong and exceptional cases". The veto, which had to be announced within three weeks if used and formally gazetted, would remain (it was later amended to a full cabinet veto which has never been used), which led Palmer to later predict that an important factor in any future success of the FOI regime would be "the attitude of public servants and Ministers to the disclosure of information will be a most important feature of the success of the legislation." 
SCHEDULE OF AGENCIES SUBJECT TO THE ACT

The implications of right-to-information laws are that the transparency of the entire government is transformed by them. However, which state agencies and which agencies contracted to the State should be subject to the OIA 1982 is still at issue even today. One focus of this research is on organisations within the privatised sector, in terms of what Alisdair Roberts calls "structural pluralism", the provision of public services through a mix of public, quasi-public and private organisations. And as the Act made its way through the parliamentary process, the length of its reach was indeed at issue, particularly for the Opposition, which complained at the broadening of the clauses that permitted secrecy (primarily sections 6 and 7) by the Governmentstacked select committee that considered the bill. Right from the start that organisations connected to the public purse were granted rights to secrecy and that Parliament's exclusion, and the ramifications of that today, was the result simply of the way the Committee on Official Information viewed the parameters of its terms of reference. The Attorney General said he agreed with the committee that including Parliament, the courts and local government under the bill was outside its brief. Local government, however, was already nominated for future inclusion in the country's FOI regime and so the automatic nature of the exclusion of Parliament never was directly explained. In 2012 a central recommendation of New Zealand Law Commission's second review of the OIA 1982 was that it be extended to the business of Parliament but the Government quickly moved to affirm the long tradition of secrecy at Parliament. When it came to quasi-autonomous non-governmenta organisations, quangos, as they were known at the time, the seeds of today's discontent over quasi-corporate bodies with connections to the public purse being excluded from $\mathrm{FOI}$ regimes were germinating even as the bill was passed. In response to a challenge from the Opposition benches, the Attorney General told the House it would "take too long to enumerate all the quangos that are excluded". He then offered examples of organisations for which exclusion took place: judicial bodies (e.g., licensing commissions), local bodies, and occupational administrative organisations (e.g., the Real Estates Licensing Board). He referred members of the House to page 104 of the Danks Committee's supplementary report on official information, which gives the principles on which exclusion of quangos was based.

Local government (city councils, district councils, regional councils, health boards, licensing boards and, after 1989, school boards) were not subject to the Act because the Danks Committee felt any openness requirements it might need, like those of Parliament and the courts, were outside its brief. But the Opposition was already of the view the right-to-know principles in the OIB must be applied to local government too, as it would be under the Labour government elected in 1984. The Local Government Official Information and Meetings Act, which effectively extended the reach of the OIA 1982 and set rules for access to local-government meetings, would be enacted in 1987.

\section{TIME LIMITS}

The law passed by Parliament in 1982 set no time limit by which the State must produce information asked for by New Zealand citizens. Instead, it required it to respond to requests as soon as practicable, a notion under fire from the Opposition in the second-reading debate on the bill. The notion of a timely response has been a point of contention ever since. Labour believed time limits should apply and was "worried that, in practice, delay will often be the most convenient course for the executive branch to take, because time has a habit of making many things less controversial". Auckland Central MP Richard Prebble said that without time limits the whole purpose of the Act would be undermined because "in many cases information delayed is information denied". It became obvious that without time limits, delays were inevitable and they were eventually introduced by Labour through amendment to the Act in 1986. The State was from then on allowed up to 20 working days to respond; either with the information requested or with its reason for either withholding the information or for needing more time.

\section{PROPOSED AMENDMENTS}

At the bill's second reading on December 14, 1981, Labour outlined its main objection: the reasons the State could withhold information, listed in sections 6 and 7, were too wide. The Government's hold on information about the economy remained too strong. The range of sanctions which could be brought against state servants releasing information that was prejudicial to the security of the nation concerned Labour. The Act was not so different to the approach taken in the OSA 1951, in that regard. National, as it turned out, agreed with this last point and sanctions would not be part of the final act at all. At that point, the OIA became entirely an FOI bill and the issue of spying, a remnant of the OSA 1951, was left to other legislation. 
The Government rejected Labour's suggested improvements at select-committee stage, during which it had found it necessary to make 22 amendments to the bill itself and was subsequently accused of rushed law-making. Closing the debate before the bill's third reading, the Attorney General dismissed Labour's amendments one by one, saying they would have threatened international relations, disadvantaged the Government in economic terms and upset a careful public-interest balance created by the select committee that considered the bill. Others would have caused trade secrets to be revealed and "imposed an arbitrary 28-day limit on the supply of information, a matter that is more than adequately dealt with by the powers of the ombudsman to investigate any undue delay in the supply of information". The issues the Opposition raised had all been "most carefully considered by the select committee" and he commended the bill to the House for its third reading. The bill was passed shortly before $4.30 \mathrm{am}$. The middle of the night was ironic time to pass a sunshine law, noted Labour's MP for St Kilda, Michael Cullen.

\section{CONCLUSIONS}

That much unimportant information flowed from the State to the citizenry in the period before the proposal for a right-to-know law was developed does not obscure the state of secrecy that remained. Questions could be asked of the Government in the House of Representatives by the Opposition but the citizenry had no forum for information gathering. Both the Government and the Opposition made it clear in the House that the FOI situation in New Zealand was no longer tenable. The weight of the issue and the importance of the law change required to solve it were heavily emphasised by both sides. One government member said he believed the rot of secrecy would eventually bring down Parliament and democracy itself. Labour proposed a solution that went further than National's. It would have narrowed the list of possible exclusions from the obligation to release information, included Parliament itself in its legal ambit and accorded the Ombudsman final powers of decision over FOI disputes. But despite these differences in the proposed solutions, the problem was very much the same from wherever you looked. An anachronistic law from earlier times, the OSA 1951, was still enabling a clandestine approach to government that went against the direction society was relatively quickly moving

Aotearoa New Zealand was a member of the first wave of libera democracies to adopt FOI laws in the second half of the $20^{\text {th }}$ century and, through that framing, it might be reasonable to attribute the passing of the OIA, in part, to common external influences. Australia and Canada, similar countries in terms of their wealth, stable libera democracies and their membership of the British Commonwealth, were passing $\mathrm{FOI}$ acts at much the same time and this trend appeared to theorists to mirror each other in important ways. Indeed, the early1950s threats from communism had now morphed into the battle between the West and the Soviet Union; the latter and militarily more sophisticated stages of the Cold War had begun and Western countries like New Zealand were keen to differentiate their stance on the rights of the citizen. These countries arguably had these political influences in common and establishing FOI regimes was a key part of asserting ownership to the moral high ground in the rejection of totalitarianism.

However, this article has shown that there was also local context to the formation of New Zealand's FOI regime that helps deepen our understanding of it. New Zealand's move to FOl corrected a damaging imbalance that had resulted from society outpacing its own laws. The OSA 1951 was restrictive and authoritarian, everything the ongoing liberalisation of social practice and the recognition of human rights sought to reject. A complete change was required and the presumption of the State's right to secrecy was flipped on its head with the enactment of the OIA 1982. It was, the Opposition argued, a rushed affair, unlikely to work properly and too favourable towards the State. But the law was designed, in technical terms, by a group which included both advocates for transparency and experts in the workings of government. As a result, the law was much more liberal than its counterparts in Canada and Australia and brought some derision from policy analysts who thought its flexibility (for example, information is not defined as necessarily being held in document form) would create havoc for the civil service. As it turned out, its flexibility was its strength, and before long the Act was being lauded as a world-leading piece of FO legislation. However, as shown in this article, seeds of discontent were evident even in the parliamentary debates that ushered in this imperfect sea-change in power relations within a democracy. Monitoring bodies that were proliferating across multiple planes of society since the end of World War II now had the power of FOI behind them as they carried out their work. It was, in a principle, the shift of the State from master to servant. 


\section{REFERENCES}

Aitken, Judith. "Open Government in New Zealand." In Open Government: Freedom of Information and Privacy, edited by Andrew McDonald and Greg Terrill. London: Macmillan, 1998.

Banisar, David. Freedom of information around the world: A global survey of access to government information law, 2006. papers.ssrn.com/sol3/papers.cfm?abstract $\mathrm{id}=1707336$

Birkinshaw, Patrick. "Freedom of information and openness: Fundamental human rights?" Administrative Law Review, 58 (2006): 177 218.

Committee on Official Information. Genera/ Report, 1980. www.ombudsman.parliament. $\mathrm{nz} /$ resources-and-publications/liberty

Cullen, Michael. "Official Information Bill Second reading." New Zealand Parliamentary Debates, 449 (1981). www.parliament.nz/en/ $\mathrm{pb} /$ hansard-debates/historical-hansard/

Ecclestone, Andrew. "How do we solve a problem like the Official Information Act?" Stuff. September 26, 2019. www.stuff. co.nz/national/politics/opinion/116079820/ how-do-we-solve-a-problem-like-the-officialinformation-act? rm=a

Ellis, Gavin. Complacent nation. Wellington: Bridget Williams Books, 2016

Elwood, Brian. "The New Zealand model - the Official Information Act 1982." In FOI and the Right to Know Conference, Melbourne: September, 1999. www.humanrightsinitiative. org/programs/ai/rti/international/laws_papers/ newzealand/the\%20new\%20zealand\%20 model\%20\%20the\%20official\%20 informatin\%20act\%201982.pdf
Espiner, Guyon. "The reformer - Geoffrey Palmer: Prime Minister 1989-90." Radio New Zealand, April 7, 2017, www.radionz.co.nz/ programmes/the9thfloor/story/201839427/the reformer-geoffrey-palme

Fensome, Alex. "Cartoonist Tom Scott always quick on the draw." Stuff. November 28, 2014 www.stuff.co.nz/national/63662317/cartoonisttom-scottalways-quick-on-the-draw

Keane, John. "Monitory democracy?" In The future of representative democracy, edited by Sonia Alonso, John Keane and Wolfgang Merkel, 81-102. Cambridge, England: Cambridge University Press, 2011.

Lidberg, Johan. "Keeping the Bastards Honest: The Promise and Practice of Freedom of Information Legislation." Doctoral thesis, Murdoch University, 2006. http:// researchrepository.murdoch.edu.au/157/

Macdonald, Nikki. "Government to rewrite Official Information Act." Stuff. July 7 2020. www.stuff.co.nz/national/122045312/ government-to-rewrite-official-information-act

McLay, Jim. "Official Information Bill Introduction." New Zealand Parliamentary Debates, 439, 1981. www.parliament.nz/en/pb/ hansard-debates/historical-hansard/

McLay, Jim. "Official Information Bill - Second reading." New Zealand Parliamentary Debates, 449, 1981. www.parliament.nz/en/pb/hansarddebates/historical-hansard/

Minogue, Mike. "Official Information Bill Introduction." New Zealand Parliamentary Debates, 439, 1981. www.parliament.nz/en/ $\mathrm{pb} /$ hansard-debates/historical-hansard/ Official Information Act, 1982
New Zealand Law Commission. The public's right to know: Review of the official information legislation, June, 2012. www. lawcom.govt.nz

Palmer, Geoffrey. "Official Information Bill - Introduction." New Zealand Parliamentary Debates, 439, 1981. www.parliament.nz/en/pb/ hansard-debates/historical-hansard/

Palmer, Geoffrey. "A hard look at the New Zealand experience with the Officia Information Act after 25 years." In Internationa/ Conference of Information Commissioners, Wellington, November 2007. www. lawcom. govt.nz

Prebble, Richard. "Official Information Bill - Introduction." New Zealand Parliamentary Debates, 439, 1981. www.parliament.nz/en/pb/ hansard-debates/historical-hansard/

Prebble, Richard. "Official Information Bill Second reading." New Zealand Parliamentary Debates, 449, 1981. www.parliament.nz/en/pb/ hansard-debates/historical-hansard/

Roberts, Alisdair. Blacked Out: Government Secrecy in the Information Age. New York: Cambridge University Press, 2006

Shroff, Marie. "The Official Information Act and privacy: New Zealand's story." In FOI Live 2005 Conference, London, 2005. www.privacy. org.nz

Snell, Rick. "The Kiwi Paradox: A Compariso of Freedom of Information in Australia and New Zealand." Federal Law Review, 28 (2000) $575-616$.

Te Ara. Story: Freedom of official information - from secrets to availability, June 20, 2012. www.teara.govt.nz/en/freedom-of-officialinformation/page-1
Thompson, David. "Questions for written answer." New Zealand Parliamentary Debates, 449, 1981. www parliament nz/en/pb/ hansarddebates/historical-hansard/

Treadwell, Greg. "FOI Scholarship Reflects a Return to Secrecy." Pacific Journalism Review 22, no. 1 (2016): 121-136.

Treadwell, Greg. "Hobbling the news: A study of loss of freedom of information as a presumptive right for public-interest ournalists in Aotearoa New Zealand." Doctora thesis, Auckland University of Technology, 2018. https://openrepository.aut.ac.nz/ handle/10292/12595

Waitangi Tribunal. Orakei, Bastion Point: Case study of a claim to the Waitangi Tribunal. Wellington: Department of Justice, 1990.

White, Nicola. Free and Frank: Making the Official Information Act 1982 Work Better. Wellington: Institute for Government and Policy Studies, 2007.

Wilde, Fran. "Questions for written answer." New Zealand Parliamentary Debates, 449, 1981. www.parliament.nz/en/pb/ hansarddebates/historical-hansard/ 